\title{
Erratum to: Focal salvage therapy for local prostate cancer recurrences after primary radiotherapy: a comprehensive review
}

D. A. Smit Duijzentkunst ${ }^{1} \cdot$ M. Peters ${ }^{1}(1) \cdot$ J. R. N. van der Voort van $\mathbf{Z y p}^{1}$ •

M. A. Moerland ${ }^{1} \cdot$ M. van Vulpen ${ }^{1}$

Published online: 20 December 2016

(C) Springer-Verlag Berlin Heidelberg 2016

\section{Erratum to: World J Urol (2016) 34:1521-1531}

DOI 10.1007/s00345-016-1811-9

One of the co-author's family name has been published incorrectly. The correct family name should read as Smit Duijzentkunst (D. A. Smit Duijzentkunst).

The online version of the original article can be found under doi:10.1007/s00345-016-1811-9.

M. Peters

M.Peters-10@umcutrecht.nl

1 Department of Radiation Oncology, University Medical

Centre Utrecht, Q.02.2.314, Heidelberglaan 100, 3584

CX Utrecht, The Netherlands 